\title{
Marriage Agreement During Marriage (A Postnuptial Agreement) Principle of Publicity as a Legal Protection for Creditors
}

\author{
Werdiningsih $^{1} \quad$ Dominikus Rato $^{2} \quad$ M. Khoidin ${ }^{3} \quad$ Aries Harianto $^{3}$ \\ 1.Doctorate Students at Faculty of Law, University of Jember \\ 2.Professor and Lecturer at Faculty of Law, University of Jember \\ 3.Doctor and Lecturer at the faculty of Law, University of Jember
}

\begin{abstract}
The Constitutional Court Decision Number 69/PUU/XII/2015 has an impact on the concept of a marriage contract that has applies in Indonesia. A marriage contract is known as a pre-nuptial agreement or pre-marital agreement in accordance with Article 29 paragraph (1) of the Law on Marriage, which states that a marriage contract can only be made before or when the marriage is in progress. The Indonesian people finally recognize the post nuptial agreement or post marital agreement in accordance with the Constitutional Court Decision which states that a marriage agreement can be made at the time, before it takes place or during the marriage bond. The court's decision raises legal uncertainty regarding the time of making the contract considering the essence of the previous marriage agreement is to prevent problems arising after the marriage has taken place. The principle of publicity of a post nuptial agreement is indicated to have several weaknesses that can harm third parties or creditors. Therefore, the researcher focuses on analyzing several problems, namely regarding the nature of the marriage contract according to the perspective of legal regulations in Indonesia, the binding strength of the publicity principle in the post nuptial agreement and the formulation of the publicity principle of the marriage agreements to provide legal protection for creditors.
\end{abstract}

Keywords: Marriage Agreement, Principle of Publicity, Creditor

DOI: $10.7176 / \mathrm{JLPG} / 101-14$

Publication date:September $30^{\text {th }} 2020$

\section{Introduction}

Marriage institutions in Indonesia are identical with various laws, it is due to the diversity of ethnicities, customs and cultures of the Indonesian people arising to many different rules according to the groups of society. These groups existed before the Dutch government enforced the 'regeringsreglement' (laws governing colonial rule) which later became the 'Indische Staatsregeling' (Indonesian State Administration during the Dutch era). An idea arose to hold a legal unification which aims to enforce a national legal provision which applies to all Indonesian people. This unification gave birth to a law, namely Act No.1 of 1974 concerning Marriage (hereinafter referred to as the Marriage Law or UUP). In order to concretize the idea of unification, Article 66 of the Marriage Law eliminates legal differences that previously applied.

Marriage is a legal union between a man and a woman to live together for a long time. The Civil Code or Burgerlijk Wetboek (hereinafter referred to as BW) considers marriage only from a civil relationship. The definition is based on Article 26 of BW, which means that the law considers marriage to be valid when its requirements according to the law are fulfilled. This article only concerns on juridical factors (Article $26 \mathrm{BW}$ ). Whereas in the UUP, it is stated that marriage is a physical and spiritual bond between a man and a woman as husband and wife which aims to form a happy and eternal family based on the Believe in One God. Marriage is sacred and is embodied in all religious teachings. It is expected to build respectable relationships between men and women, ${ }^{1}$ peaceful married life, and affection among family members, ${ }^{2}$ all of which lead to family harmony. Marriage not only unites a man and woman in a family but also brings legal consequences for both the wife and the husband who are legally married. The various legal consequences arose are the rights and obligations of each party during the marriage, their responsibilities to children, the consequences for assets, both joint and individual assets, and the legal consequences for third parties. It is important for every prospective married couple to understand to prevent problems occurs in their marriage. Sometimes to prevent problems in the future regarding property and wealth, the parties who wish to get married make a marriage agreement (huwelijksvoorwaarden) first. $^{3}$

Indonesian law clearly states that the Marriage Agreement is made before the marriage takes place or at the time the marriage ceremony is taking place. According to article 29 of the Marriage Law, it is stated that at the time or before the marriage takes place, both parties can make written agreement which is legalized by the Marriage

\footnotetext{
${ }^{1}$ Abd. Nashr Taufik Al-Athar, Saat Anda Meminang, Terj. Abu Syarifah dan Afifah, Jakarta: Pustaka Azam, 2000. P. 5

${ }^{2}$ Ahmad Azhar Basyir, Hukum Perkawinan Islam, Yogyakarta: Fakultas Hukum Universitas Islam Indonesia, 1995. P. 1

${ }^{3}$ Subekti, Pokok-Pokok Hukum Perdata, Jakarta: Intermasa, 1993- 25 ${ }^{\text {th }}$ Edition. P. 37
} 
Registration Officer, which the contents also apply to third parties as long as the third party is involved. This agreement cannot be ratified if it violates legal, religious and moral boundaries (article 29 paragraph 2 of the Marriage Law). However, since March 21st, 2016, the Constitutional Court has granted a request for a judicial review of Article 29 paragraph (1) of the Marriage Law through the Constitutional Court Decision Number 69 / PUU-XIII / 2015 of 2015. Article 29 paragraph (1) of the Marriage Law previously have limited the making of a marriage agreement for separation of assets after the marriage has taken place because the agreement must be made before the marriage can take place. Article 29 paragraph (1) of the Marriage Law stated: "At the time or before the marriage takes place, the two parties with mutual consent can make a written agreement which is legalized by the marriage registrar, after which the contents also apply to third parties as long as the third party is involved." However, with the Constitutional Court Number 69 of 2015, the provisions of Article 29 paragraph (1) of the Marriage Law have been amended as follows: Article 29 paragraph (1) of the Marriage Law jo. Constitutional Court Decision 69/2015 stated: "At the time, before or at the moment the marriage is taking a place, the two parties can make mutual written agreement legalized by a marriage registrar or a notary, which the contents also apply to third parties as long as the third party is involved." The Constitutional Court Decision no 69/2015 has expanded the meaning of a marriage agreement so that a marriage agreement is no longer interpreted as an agreement made before marriage (prenuptial agreement) but it can also be made after the marriage takes place (postnuptial agreement). The Constitutional Court has made extensive interpretations of the period for making agreement.

Based on the above description, various problems of marriage agreements made during the marriage bond are: First, the philosophical problem, that the marriage agreement made while in the marriage tie negates the aspects of marriage religiosity which integrates the totality of marriage including marital assets division. The religiosity of marriage is basically a manifestation of the need for worship guaranteed and facilitated by the state. Second, the juridical problem, that the Constitutional Court's decision that points the notary as an authoritative institution - determining the validity of the marriage agreement is contrary to Article 15 of the Act No.2 of 2014 concerning Amendments to Act No.30 of 2004 concerning the Position of Notary, considering that none of the provisions regulate the authority of a notary to ratify a marriage agreement made during the marriage tie. The authority of the notary is basically motivated by the principle of publicity which is actually contrary to the principle of notary confidentiality. This is where a regulatory vacuum occurs which creates uncertainty on legal protection for creditors as third parties. Third, the theoretical problem, the regulation of the marriage agreement during the marriage bond indicates the absence of both internal and external legal protection for creditors, as the idea of the Legal Protection Theory. Fourth, the sociological problems, the Constitutional Court's new interpretation of the marriage agreement increasing the possibility of disputes between the parties making the marriage agreement and creditors as a third party. The third party has the potential to be harmed as a result of the marriage agreement made during the marriage bond. Therefore, regarding these legal problems this research entitled the Principle of Publicity of Marriage Agreements During Marriages (Post Nuptial Agreement) as a Form of Legal Protection for Creditors. Researchers focused on first, the nature of the marriage agreement according to the perspective of legal regulations in Indonesia, the second is the binding strength of the principle of publicity in the arrangement of a marriage agreement (post nuptial agreement) during the marriage period to provide legal protection for creditors, and the third is the formulation of the principle of publicity in regulating marriage agreements (post nuptial agreement) to provide legal protection for creditors.

\section{Research Method}

The juridical normative method is applicable to this research. This method examines various formal legal regulations such as laws and literatures containing theoretical concepts which are then linked to legal issues of the subject to obtain a conclusion that is in accordance with scientific truth and can be accounted for scientifically and objectively. ${ }^{1}$ Normative juridical research is commonly called a doctrinal research, i.e., a research that aims to provide detailed and systematic explanations carried out by examining various legal rules, analyzing the relationship between one regulations and another, and even to predict the development of legal rules in the future. ${ }^{2}$ Soejono and Abdurrahman argued that the object of doctrinal legal research were documents of statutory regulations and literature reviews. ${ }^{3}$ It shows that the purpose of using doctrinal legal research is to systematize, correct and clarify a legal rule that applies to certain areas of law through the analysis of primary legal materials and secondary legal materials, ${ }^{4}$ it is related to the Publicity Principle Post Nuptial Agreement As a Form of Legal Protection for Creditors.

The approaches applied to this research are the historical approach, i.e., analyzing the history of the enactment of the Marriage Law, the minutes of formation and legal politics concerning marriage agreements applicable in

\footnotetext{
${ }^{1}$ Peter Mahmud Marzuki, Penelitian Hukum, Jakarta: Kencana Prenada Media Grup, 2010. P.96

${ }^{2}$ Dyah Ochtorina Susanti dan A'an Efendi, Penelitian Hukum (Legal Research), Jakarta: Sinar Grafika, 2014. P. 11

${ }^{3}$ Soejono dan Abdurrahman, Metode Penelitian Hukum, Jakarta: Rineka Cipta, 2003. P. 56.

${ }^{4}$ Dyah Ochtorina Susanti dan A'an Efendi. Op. Cit., P. 15.
} 
Indonesia and the Constitutional Court Decisions. This approach traces the views and doctrines develop in legal science resourcing from the experts' opinions or laws and regulations. The case approach is studying the legal norms or rules carried out in legal practice. This approach is done by reviewing the court decisions, especially the Constitutional Court decision Number 69/PUU-XIII/2015. The statute approach is an approach examining all laws and other laws, laws nd the Constitution or between regulations and laws regarding Marriage Agreements. The comparative approach is carried out by conducting a comparative legal study. ${ }^{1}$ According to Van Apelddorn, comparative law is an auxiliary science for dogmatic law to assess the existing legal rules and court decisions to other legal systems. ${ }^{2}$ Comparisons will be made between several countries with the same legal system. The legal system classification is based on family law in which Indonesia adheres to the Civil law.

\section{Results and Discussion}

\section{a. The Marriage Agreement Based on Indonesian Legal Perspective}

Indonesia has a variety of customary laws and religious beliefs embraced by the community. This diversity leads to various kinds of legal provisions which have a major influence on the enforcement of law in Indonesia, including the institution of marriage. This legal pluralism has existed since the days of the Dutch East Indies which was also supported by several factors, including: (1) The politics of the Dutch East Indies government; (2) The absence of national legal provisions; and (3) ethnicity. ${ }^{3}$ The Dutch came with a new marriage law arranged in the form of legislation as stated in the Burgerlijk Wetboek (BW). The existence of BW prevailing in Indonesia historically cannot be separated from the Dutch "Burgerlijk Wetboek" and the French "Civil Code". Likewise, the French Civil Code has largely taken over the Roman law. This historical linkage is based on a concordance principle (concordantie beginsel). The BW codification in the Netherlands was legalized through the Koninklijk Besluit dated April 10, 1838 which was declared valid since October 1, 1838. Through the Dutch East Indies General's announcement dated December 8, 1847, it was declared valid since May 1, 1848 in Indonesia. ${ }^{4}$ In fact, due to demands from the needs of the Dutch, new legal regulations were born such as Huwelijks Ordonnantie Christen Indonessiers S 1933 Number 74 (HOCI), Regeling op deGemengde Huwelijken S 1898 Number 158 (GHR). When the Dutch came to hold the power, at the moment, various kinds of marriage laws were enforced in Nusantara. The diversity was in line with the division of population groups in the Dutch East Indies based on Article 131 jo 163 Indische Staatsregeling (IS). ${ }^{5}$ The enforcement of marriage laws for various groups of community and various regions are as follows: ${ }^{6}$

d) Religious law prescribed in the Customary Law applied for Muslim Indigenous;

e) The customary law applied for other native Indonesians;

f) Huweliksordonnantie Christen Indonesia applied for Christian Indonesians (S. 1933 Number 74);

g) For Chinese foreigners and Chinese Indonesians, the provisions of the Civil Code apply with minor changes;

h) Their customary law applies to other Foreign Easterners and Indonesian citizens of other Foreign Eastern descent.

i) The civil law codes applied for Europeans and Indonesian citizens of European descent and their equivalents, The above illustration reveal that during the Dutch colonial era, the pluralism of marriage law was strongly characterize the condition of society. Later, the fact shows that even though the Dutch colonialism has ended, the pluralism of the marriage law continues. Until at the end of 1974, the Indonesian government finally succeeded in issuing Act Number 1 of 1974 concerning Marriage (hereinafter referred to as the Marriage Law). The birth of the Marriage Law as a constitutional mandate is a major milestone that ends the era of pluralism of the marriage law that had applied for a long time in the country. The issuance of the Marriage Law is a step towards an era of unification of the marriage law in the country, thus, all Indonesian citizens should comply with the same rules for marriage related matters namely the Marriage Law. ${ }^{7}$ Marriage is a legal act that has legal consequences for both husband and wife. These consequences are then described by law with further and detailed regulations. Article 35 of the Government Marriage Law regulates legal consequences in the field of assets, which is almost the same as the provisions in Article $119 \mathrm{BW}$, although with a different pattern. Regarding the marriage agreement Article 29 of the Marriage Law. The article states that: "At the time or before the marriage takes place, both parties to a collective agreement can make a written agreement legalized by the marriage registrar which the contents also apply to the third party as long as the third party is involved". The Article is regulated as follows:

1) At the time or before the marriage takes place, both parties to a collective agreement can make a written agreement legalized by the marriage registrar which the contents also apply to the third party as long as the

\footnotetext{
${ }^{1}$ Ibid

${ }^{2}$ P. Van Dijk, Van Apeldoorn's Inleiding tot de Studie van het Nederlanse Recht. Tjeenk-willijnk. 1985. P. 453

${ }^{3}$ Titik Triwulan tutik. Hukum Perdata Dalam Sistem Hukum Nasional. Jakarta: Kencana, 2008. P. 4

${ }^{4}$ Tan Kamello dan Syarifah Lisa Andriati. Hukum Orang dan Keluarga. Medan: USU Press, 2011. P.11

${ }^{5}$ Moch. Isnaeni. Hukum Perkawinan Indonesia. Bandung: Refika Aditama, 2016. P. 12

${ }^{6}$ Sudarsono. Hukum Perkawinan Nasional. Jakarta: Rineka Cipta, 1991. P. 6-7

${ }^{7}$ Moch. Isnaeni. Op.,Cit. P. 18
} 
third party is involved.

2) The agreement cannot be ratified if it violates the boundaries of law, religion, and morality.

3) The enactment of agreement starts since the marriage takes place.

4) During the marriage is taking a place, the agreement cannot be changed, unless there is an agreement from both parties to change it as long as it does not harm the third party. ${ }^{1}$

Reviewing the formulation of the Article, it is concluded that the Marriage Law does not clearly stated the meaning of marriage agreement especially regarding matters relating to the scope or content that a future husband and wife can arrange in a marriage agreement. ${ }^{2}$ Comparison between marriage regulations in the Marriage Law and the BW arrangement is done to find a better understanding. The marriage agreement is regulated in article 119 BW. The article stipulates: "From the moment the marriage takes place, the unanimous union between the husband and wife's assets shall apply in legal. There is no other provision made related to the marriage agreement." Furthermore, Article 139 BW stipulates that: By making a marriage agreement. Both future husband and wife are entitled to prepare several deviations from the statutory regulations regarding the association of assets. As long as the covenant does not violate morality or general order. ${ }^{3}$ The formulation of Article 29 of the Marriage Law, and Article $139 \mathrm{BW}$ contains similar elements. In addition to those similarities, the arrangement of the marriage agreement in BW and the Marriage Law also have some differences. These elements are as follows:

1. Made by Couples before the Marriage Takes Place

Article 47 BW determines the threat of cancellation, every marriage agreement must be made with a notary deed before marriage takes place. Whereas in Article 29 of the Marriage Law it is determined that at the time or before the marriage takes place, the couples can make a written agreement, in which the content also apply to third parties.

2. Made in Written Form

A marriage agreement, is an agreement made by couples before marriage (or according to the Marriage Law it can also be during the marriage) and is made in a written form. The provisions of Article 29 stated that it is more important if it is made in the form of an authentic deed, because there are clauses that also apply to third parties. (Comparing the provisions of Articles 1868, 1870, 1876, 1875, $1877 \mathrm{BW}$ ). ${ }^{4}$

Subekti stated a private deed has a power like an authentic deed if the proof is perfect for the parties, not for the third party. Meanwhile, according to Nurnazly Soetarno, the marriage agreement is meaningless when it is made by underhand. ${ }^{5}$

The community does not acknowledge the existence of the marriage agreement, and the proof is not strong, because it is still debatable, whereas even if it is acknowledged, the underhand deed has perfect evidentiary power only for the parties. Therefore, he also stated that the marriage agreement should be made in the form of an authentic deed. ${ }^{6}$

3. Elements of Decency and Public Order

The elements of decency and public order in Article 139, are also contained in Article 29 paragraph 2 of the Marriage Law, the marriage agreement must not violate legal, religious and moral boundaries.

4. Elements Cannot Be Changed

This element is revealed in Article 149 BW, which stipulates that after the marriage takes place the marriage agreement cannot in any way be changed.

The Marriage Law also formulated the marriage agreement in principle cannot be changed, although in paragraph 4, it contains a slight differences that the agreement can be changed if both parties, husband and wife, agreed. According to BW, the marriage agreement in any way cannot be changed after the marriage has taken place.

5. Elements of the Validity of the Marriage Agreement

Regarding this element, Article $147 \mathrm{BW}$ stipulates that the marriage agreement is valid since the marriage is taking place. It cannot be stipulated other than this time. It is in accordance with the formulation of Article 29 paragraph 3 of the Marriage Law, which states that the marriage agreement is valid from the moment the marriage takes place.

The existence of similar elements in the arrangement of marriage agreements in BW and the Marriage Law on Marriage, it is intended to regulate the same legal institution. The legal institution in the marriage agreement

\footnotetext{
${ }^{1}$ Tengku Erwinsyahbana, "Sistem hukum perkawinan pada Negara hukum berdasarkan pancasila," jurnal ilmu hukum, Vol. 3, No. 1, 2012, P. 5 .

${ }^{2}$ M. Alvi Syahrin, “Actio Pauliana: Konsep Hukum dan Problematikanya,” Lex Librum: Jurnal Ilmu Hukum, Vol. 4, No. 1, 2017., P. 8.

${ }^{3}$ Herlien Budiono, Ajaran Umum Hukum Perjanjian dan Penerapannya di Bidang Kenotariatan, Citra Aditya Bakti, $2011 .$, P. 14.

${ }^{4}$ Annisa Istrianty dan Erwan Priambada, "Akibat Hukum Perjanjian Perkawinan Yang dibuat Setelah Perkawinan Berlangsung," Sebelas Maret University Privat Law, Vol. 3, No. 2, 2016., P. 64.

${ }^{5}$ Raden Subekti, Aneka perjanjian, Penerbit Press Citra Aditya Bakti,1995., P. 19.

6 Erdhyan Paramita, Akibat Hukum Perjanjian Perkawinan Yang Tidak Disahkan Oleh Pegawai Pencatat Perkawinan, Jurnal Repertorium Volume IV No. 2 Juli - Desember 2017, P. 6.
} 
both regulated in BW and The Marriage Law are the same, although there are elements of differences too. ${ }^{1}$ The provisions of Article 29 of the Marriage Law are a form of deviation from the provisions of Article 35 of the Marriage Law which regulate marital property. ${ }^{2}$ The concept of marital property in the Marriage Law is different from the concept of marital property in BW. The provisions of Article 35 of the Marriage Law states that:

1. Assets acquired during the marriage ties become joint assets;

2. The inheritance of each husband and wife and the property obtained by each as a gift or inheritance is under their respective control as long as the parties do not determine other things.

BW regulates marriage agreements in several articles, in contrary to the Marriage Law which only regulates marriage agreements in one article. This condition seems to indicate that the Marriage Law provides freedom and opportunity for the prospective husband and wife to regulate their own marital assets by not violating law, morality and religious value. The significant similarity between BW and the Marriage Law is that agreements can only be made prior to their marriage and legalized at the time the marriage is taking place. However, by the existence of the Constitutional Court Decision Number 69 of 2015 concerning Basic Agrarian Principles and Act Number 1 of 1974 concerning Marriage against the 1945 Constitution of the Republic of Indonesia, the provisions of Article 29 paragraph (1) of the Marriage Law have changed so as to expand the meaning of the marriage agreements. A marriage agreement is no longer interpreted as an agreement made before marriage (prenuptial agreement) but can also be made after the marriage takes place (postnuptial agreement). The Constitutional Court has made extensive interpretations on the period for the agreement. The basis for considerations (ratio decidendi) of the Constitutional Court Decision regarding the purpose of making the Marriage Agreement are: ${ }^{3}$

1) Separating the husband and wife's assets. Therefore, if one day they decide to divorce, their each assets are protected. Conflict of assets divisions will not occur.

2) For the debts of each party that they incurred in their marriage, each will be responsible separately.

3) If one of the parties wants to sell their assets, they do not need to ask permission from the spouse (husband / wife).

4) Likewise with the credit they applied for, they no longer have to ask prior permission from their spouse (husband / wife) in terms of pledging the assets registered under one of their names.

From the above description, it shows that the state has regulated marriage agreements since the enactment of BW until the Constitutional Court Decision. These regulations provide space to determine the nature of the marriage agreement which can be seen from the ontological, epistemological and axiological aspects. The ontological aspect is the understanding of the nature of the agreement with the values of a property in a marriage between the prospective bride and wife. In the Indonesian context, the basic essence of the ontology that underlies the marriage agreement, even though it has freedom of regulation, must still be sourced from the values of Pancasila as contained in the Preamble to the 1945 Constitution which became the grundnorm of the Republic of Indonesia. While the epistemological aspect is a philosophical effort to understand the nature of truth and knowledge that the human ratio can achieve on the law of the marriage agreement so that it can be carried out properly by the prospective bride and wife without harming third parties who have interests. The axiological aspect seeks to know the essence of the values contained in the marriage agreement law.

The Constitutional Court's decision that "the Marriage Agreement taken after marriage, valid from the time the marriage takes place, unless it is stipulated specifically in the Marriage Agreement," is not appropriate since it will cause legal uncertainty. ${ }^{4}$ The enactment of a Marriage Agreement made after marriage can cause new problems, namely regarding legal certainty over the legal position of joint property obtained by husband or wife since the marriage took place to the date the Marriage Agreement is made. ${ }^{5}$ It could change the legal status of existing assets. Moreover, the marriage agreement taken into after the Constitutional Court decision, makes the agreement can be made at any time. It arises problems related to property existed, according to law it is as joint property of the spouse since it is obtained during their marriage. ${ }^{6}$ This provision contained in Article 35 paragraph (1) of the Marriage Law, that assets obtained during marriage become joint assets. Furthermore, the Constitutional Court Decision can cause new problems, namely relating to public order. Because Article $1131 \mathrm{BW}$ states that the legal position of marriage property is a general collateral. ${ }^{7}$ In their daily life, marriage couples are involved in the

\footnotetext{
${ }^{1}$ Damian Agata Yuvens, "Analisis Kritis terhadap Perjanjian Perkawinan dalam Putusan Mahkamah Konstitusi Nomor 69/PUU-XIII/2015," Jurnal Konstitusi, Vol. 14, No. 4, 2018, P. 11.

${ }^{2}$ Oken Shahnaz Pramasantya, "Perjanjian Perkawinan Pasca Putusan Mahkamah Konstitusi Nomor 69/PUU-XIII/2015," Jurnal Cakrawala Hukum, Vol. 8, No. 2, December, 2017, P. 194.

${ }^{3}$ Oly Viana Agustinee, Politik Hukum Perjanjian Perkawinan Pasca Putusan Mahkamah Konstitusi Nomor 69/PUU-XIII/2015 Dalam Menciptakan Keharomonisan Perkawinan, Jurnal Rechtsvinding-Volume 6, Nomor 1-April 2017. P.61

${ }^{4}$ Syaifullahi Maslul, "Putusan Mahkamah Konstitusi Nomor 69/PUU-XIII/2015 Ditinjau dari Pemenuhan Hak-Hak Asasi Manusi dan AsasAsas Pembentukan Perjanjian," Jurnal Mahkamah: Kajian Ilmu Hukum Dan Hukum Islam, Vol. 1, No. 2, 2016, P. 409-424

${ }^{5}$ Abdul Hariss dan Nurul Wulan Kasmara, "Tinjauan Yuridis Akibat Hukum Perjanjian Harta Bersama yang Dibuat Oleh Suami Istri Setelah Perkawinan Berdasarkan Putusan Mahkamah Konstitusi Nomor 69/PUU-XIII/2015," Wajah Hukum, Vol. 3, No. 1, 2019 , P. 65.

${ }^{6}$ Dian Ety Mayasari, "Tinjauan Yuridis tentang Perjanjian Perkawinan Setelah Adanya Putusan Mahkamah Konstitusi Nomor 69/PUUXIII/2015,”, , Vol. 51, No. 1, 2017, P. 81.

${ }^{7}$ As Article 1131 of BW stated: " both existing and future movable and immovable properties belonging to debtors, are taken as collateral for
} 
community bonds. If the obligations born from an engagement involving a husband and wife are not fulfilled voluntarily, then the applicable law is a general guarantee as regulated by Article $1131 \mathrm{BW}$. But if then the position of the husband and wife's assets can be changed at any time even though it should not harm other parties, then it may be detrimental to the creditors concerned. ${ }^{1}$

The Constitutional Court's decision also stated that: "During the marriage takes place, the marriage agreement may relate to the assets of the marriage or other agreements, it cannot be changed or revoked, unless both parties agreed the change, and the amendment or revocation does not harm the third party." The result of this decision certainly feared the third party, because the husband or wife can change or withdraw the Marriage Agreement unilaterally without the knowledge of the third party. ${ }^{2}$ Moreover, they can make, change, and revoke an agreement any time they are willing to. The decision open an opportunity for the spouse to avoid and abuse their responsibility in fulfilling their debt obligations to third parties. When a party defaults, the third party can claim compensation to the District Court. It applies if the third party does not know the marriage agreement made after the marriage took place and it has not been registered. However, if the third party is aware of the existence of a registered Marriage Agreement taken after marriage is taken place, the third party may not assume that the marriage agreement does not exist. Thus, those who can file a claim are third parties who made a contract before or after the agreement was made, but the agreement has not been registered or legalized. It is due to the marriage agreement does not have permanent legal force. ${ }^{3}$ The initial provisions contained in Article 29 paragraph (1) of the Marriage Law are considered to provide more legal certainty for the parties who bind themselves in a marriage. Marriage agreements made after the marriage takes place can cause harm and injustice to third parties. The interests of third parties tend to be unprotected. ${ }^{4}$

The Constitutional Court's decision related to Article 29 paragraph (4) of the Marriage Law also needs clarification, whether the provision "not detrimental to third parties" only applies to amendments and cancellation of marriage agreements or also applies to the making of a marriage agreement during the marriage. It is important considering that an Indonesian citizen who is married to a foreigner and has owned assets in the form of land ownership rights for more than one year will make a marriage agreement during their marriage. Prior to the Constitutional Court Decision, the Constitutional Court Decision Number 69/PUUXIII/2015 it revealed that the authority of a notary in legalizing a marriage agreement cannot be equated with the authority possessed by a marriage registrar employee. Notaries are public officials in the field of private law and have the authority to make authentic deeds and other powers regulated in statutory regulations. Meanwhile, Marriage Registry Officers are officials within the scope of public law who have the authority in the field of state administrative law which regulates legal events carried out by the public.

The authority of a Notary to legalize a marriage agreement is not regulated by the Law on Notary Position (UUJN). However, the notary has the legalization authority in the UUJN, which is regulated in Article 15 paragraph (2) letter a of the UUJN which is known as legalization. ${ }^{5}$ Marriage agreement ratified or made before a notary (in the form of an authentic deed). Also applies to marriage agreements that have been previously made under hands and then legalized by a notary to have binding legal force for both parties. It is based on the pacta sun servanda principle as a fundamental principle in contract law. However, on the other hand, a marriage agreement is binding on a third party, if it is legalized by a marriage registrar as a form of fulfilling the requirements for the element of marriage agreement publicity based on the provisions of Article 29 of the Marriage Law. Therefore, a legal problem occur that a marriage agreement made by a notary does not need to be registered to a marriage registrar. This problem was triggered by the granting of authority based on the Constitutional Court Decision Number 69 / PUU-XIII/2015 to the Notary to legalized the marriage agreement, ${ }^{6}$ inherently based on his position. On the other hand, the problem arises from the meaning of the phrase "legalized by" which by the Constitutional Court decision seems to provide 2 ways of ratifying the marriage agreement, namely Legalized by a marriage registrar and by a Notary.

The second method means that the parties no longer need to record the marriage agreement because it is valid. The opinion saying that the Constitutional Court's decision gives the authority to the notary to ratify the marriage agreement is understandable considering that the grammatical construction of the sentence from the Constitutional Court decision allows such an interpretation. ${ }^{7}$ Legalization of a written agreement (which contains a marriage

\footnotetext{
debtor's individual agreement."

${ }^{1}$ Syaifullahi Maslul, Op. Cit., P. 14

${ }^{2}$ Sri Subekti, Liliana Tedjosaputro, dan Mr Mashari, "Legal Protection Concept: Separate Maintenance for the Third Party in Prenuptial

Agreement," International Journal of Civil Engineering and Technology, Vol. 11, No. 1, 2020, P. 8.

${ }^{3}$ Rahmida Erliyani, Aspek Hukum Perjanjian Perkawinan, Penerbit K-Media, 2016.P. 67.

${ }^{4}$ Sri Subekti, Liliana Tedjosaputro, dan Mr Mashari, Op. Cit., P. 12

${ }^{5}$ Habib Adjie, 2008, Hukum Notaris Indonesia: Tafsir Tematik Terhadap UU No. 30 Tahun 2004 Tentang Jabatan Notaris, Refika Aditama, P. 76.

${ }^{6}$ As stipulated in the Constitutional court Decision Number 69/PUU-XIII/2015 as Written Agreement.

${ }^{7}$ Damian Agata Yuvens, "Analisis Kritis terhadap Perjanjian Perkawinan dalam Putusan Mahkamah Konstitusi Nomor 69/PUU-XIII/2015," Jurnal Konstitusi, Vol. 14, No. 4, 2018, P. 789.
} 
agreement) and ratification of a marriage agreement on the other hand are two different things. An agreement made under hand is only binding if it is legalized by a marriage registrar, while an agreement made before a notary is considered legally binding after being signed by the parties. However, the validity of the marriage agreement is limited to between the parties themselves, it does not necessarily bind a third party. ${ }^{1}$ In other words, being legal against the parties does not mean being legal against other third parties because it does not fulfill the elements of the Publicity Principle. In this case, the Constitutional Court Decision talks about 2 scopes of enforcing the agreement. Namely the enforceability of the parties who make it and the validity of agreements against third parties. $^{2}$

Ratification of a marriage agreement by a marriage registrar or a notary public is only an additional requirement of the validity of a marriage agreement that applies to both parties, apart from the legal terms of the agreement as referred to in Article $1320 \mathrm{BW}$. In order the agreement bind a third party, as stated in the decision, a marriage agreement must be submitted. ${ }^{3}$ If it has been registered to the marriage registration office to be announced to the public, the nature of its enforcement is binding on a third party (outgoing). It is also very influential, especially for Indonesian citizens who are married to foreigners, where if the marriage agreement does not fulfill the element of publicity that the couple having joint property, the Indonesian citizen is still threatened to not have ownership rights to land in Indonesia. ${ }^{4}$ Especially with regard to third parties (creditors) protection. Furthermore, the Constitutional Court Decision also did not regulate the procedures and legal consequences of the marriage agreement in detail. It is important because when implementing regulations do not exist, it will cause obstacles in its practice.

\section{b. A Binding Power of Publicity Principle of Post Nuptial Agreement Regulation During Marriage to} Provide Legal Protection for Creditor

A marriage agreement is basically a form of contract made based on mutual agreement of a man and a woman at the moment or before their marriage. Thus, a marriage agreement must also contain the terms of the validity of the agreement, as stipulated in Article $1320 \mathrm{BW}$, namely the agreement is valid if it has fulfilled the provision of Article $1320 \mathrm{BW} .^{5}$ It must be registered, to fulfill the publicity element of the marriage agreement. In order that the third party (other than the husband and wife) knows and obeys the rules of the marriage agreement that the couple has made. If it is not registered, the marriage agreement is only valid for the parties who made it, namely the husband and wife concerned. It is based on Articles 1313, 1314 and 1340 BW where the agreement is only binding for the parties who make it. It is in line with Article 29 Paragraph (2) of the Marriage Law that the legalization has a publicity function. ${ }^{6}$

The function of recording in the public register is to fulfill the principle of publicity solely that the marriage agreement is known by third parties so that it can be enforced against the related third party. The publicity function of registration is not required for the validity of the marriage agreement to the husband and wife who made it, because by making and signing the marriage agreement themselves, it is certain that they — the husband and wife - have known the agreement they made. Referring to Article 1338 of the BW Book, the agreement will be legally binding for the couples who made it, and must be implemented in good faith. ${ }^{7}$ Regarding the application of the principle of publicity in the realm of law, it can be understood that from the principle of publicity itself is actually a notification or announcement to other parties or third parties regarding legal events occurring. The legalization of the marriage agreement carried out by the Marriage Registrar has an element of publicity to a third party related to the existence of the marriage agreement. ${ }^{8}$ Thus, to fulfill the publicity element of the marriage agreement, it must be legalized by a Marriage Registrar at a predetermined agency, the importance of this ratification so that the third party knows and is subject to the marriage agreement, for example sale and purchase made by a husband or wife, if a marriage agreement exist, then it will bind them in the legal action they will perform. The legalization made by the marriage registrar is only to record the marriage agreement which will later be contained in the marriage certificate. Thus, the third party concerned will understand the marriage agreement. ${ }^{9}$ Regarding the registration of a marriage agreement, the agreement applies to a third party after the agreement deed is registered in the general register at the Registrar's Office at the District Court. It is in line with the provisions in Article 152 BW which aims to provide opportunities for third parties to find out about the marriage agreement (publicity

\footnotetext{
${ }^{1}$ Sebagaimana hal ini disebut sebagai Asas Kepribadian.

${ }^{2}$ Habib Adjie, 2009, Sekilas dunia Notaris \& PPAT Indonesia: kumpulan tulisan, Mandar Maju, P. 49.

${ }^{3}$ It is considered as a form of marriage registration.

${ }^{4}$ Herlien Budiono, Op. Cit., 19, P. 64.

${ }^{5}$ Wisda Rauyani Efa Rahmatika dan Akhmad Khisni, “Analisis Yuridis Atas Perjanjian Perkawinan Ditinjau Dari Undang-Undang No.1 Tahun 1974 Tentang Perkawinan Dan Implikasi Putusan MK No.69/PUU-XIII/2015,” Vol. 4, No. 3, 2017, P. 10

${ }^{6}$ Ibid., P. 5.

${ }^{7}$ Sylvia Widjaja, Aneka Permasalahan Mengenai Perjanjian Kawin Pengesahan Atau Pencatatan. P. 88

${ }^{8}$ Arief Cholil, "Implementation Agreement By Mixed Marriage Based On Act No. 1 of 1974 Concerning Marriage After Constitutional Court Ruling No. 69 / PUU-XIII / 2015 (Study of Notary Role),”Vol. 5, No. 4, 2018, P. 8, . 5.

${ }^{9}$ Erdhyan Paramita, Akibat Hukum Perjanjian Perkawinan Yang Tidak Disahkan Oleh Pegawai Pencatat Perkawinan, Jurnal Repertorium Volume IV No. 2 Juli - Desember 2017. P. 36
} 
principle). On the other hand, It does not apply after the existence of the Marriage Law on all forms of publicity principles of marriage agreements which are submitted to marriage registration officers as stated in the Supreme Court Decree No. 585 K /Pdt/ 2012.

A marriage agreement, in order to be binding for a third party - should be legalized by a marriage registrar, it is in accordance with the provisions stipulated in Article 29 of the Marriage Law which states that before the marriage takes place, the two parties with mutual consent can enter into a written agreement which legalized by 2 marriage registrar after which the issue also applies to the third party as long as the third party is involved. ${ }^{1}$ On the other hand, a marriage agreement can be binding for the parties who make it and also the third party in the contents of the marriage agreement. Both parties should fulfill the agreements made, as long as it does not harm any party. ${ }^{2}$ This agreement should not be violated, since it can have legal implications. Violation can cause marriage agreement doubtful and interfere with the achievement of the marriage goal. The marriage agreement must be registered to fulfill the publicity element of the agreement so that the third party (other than the husband or wife) knows and obeys the rules of the marriage agreement that the couple has made. ${ }^{3}$ If it is not registered, it is only binding/valid for the parties who made it, i.e., the husband and wife concerned. Legal protection for assets in marriage, according to $\mathrm{BW}$ is given the freedom to determine the contents of the marriage agreement to make deviations from the provisions contained in BW regarding the association of assets but with this limitation: The marriage agreement must not conflict with morality and public order (Article $139 \mathrm{BW}){ }^{4}$

The legal power of a marriage agreement is related to the binding strength of the agreement to the parties making it. However, it should be noted that in addition to being valid for married couples, marriage agreements can also be binding on third parties. This agreement must be ratified (fulfilling the principle of publicity). It begins to bind and apply to married couples since the marriage is declared valid and has been carried out according to the law of each religion and belief and the marriage is registered according to statutory regulations (Article 2 of the Marriage Law). By the Constitutional Court Decision Number. 69/PUU-XIII/2015 the validity period of the marriage agreement which is made starting from the time the marriage took place, however, the parties can determine other matters in the marriage agreement concerned, for example, it is starting to take effect as of the date of marriage agreement is made. The validity of the agreement cannot be separated from the provisions of the legal terms of the agreement in general. Based on Article $1320 \mathrm{BW}$ an agreement must be made by fulfilling four conditions, namely: ${ }^{5}$

a. Their agreement which binds itself;

b. The ability to make an engagement;

c. A certain subject matter; and

d. A cause that is not forbidden.

The element of publicity as stated in the provisions of Article 29 Paragraph (1) of the Marriage Law is not intended to determine the validity of a marriage agreement because the criteria for determining the validity can be found in Article 29 Paragraph (2) of the Marriage Law which stipulates that the agreement cannot be ratified if it violates the legal, religious and ethical boundaries. Contradictions of the Marriage Agreement Deed in the Decision of the Indonesian Constitutional Court and the Letter of the Directorate General Number 472.2/5876/Dukcapil. ${ }^{6}$ a marriage agreement is classified in an agreement of the law regarding evidence meaning that the party's intention is a violation of the evidence. ${ }^{7}$ On the other hand, avoiding reversed evidence with the provisions of the agreement will not be contrary to compelling law. A coercive provision arises when the regulator specifically wants to protect one party and also intends to provide protection to a third party.

The Legalization of a marriage agreement means "the act of ratifying, legal recognition, formalization or justification". ${ }^{8}$ According to the law, ratification is a legal action by the competent authority to change the status of "invalid" to legal as well as changing from a non-legal entity to a legal entity. It is different from the legalization made by the Marriage Registry Officer. ${ }^{9}$ The registrar must thoroughly examine whether or not the marriage agreement contains matters that violate legal, religious and moral boundaries. The Article 29 Paragraph (2) of the Marriage Law stated that: "A marriage agreement cannot be ratified by a Marriage Registry Officer if it violates these boundaries, it is considered a contrario that after being legalized by a Marriage registrar, it means that the

\footnotetext{
${ }^{1}$ Reza Fahlevi Bachtiar, "Due To Legal Marriage Without Married Agreement Relating To The Existence Of Bankruptcy,” Vol. 5, No. 2, 2018, P. 6

${ }^{2}$ Endang Sumiarni, Kedudukan Suami Isteri Dalam Hukum Perkawinan, Kajian Kesetaraan Jender Melalui Perjanjian Kawin, (Yogyakarta: Wonderful Publishing Company, 2004), P. 159

${ }^{3}$ Reza Fahlevi Bachtiar, Op. Cit., 95, P. 6.

${ }^{4}$ Ibid.

${ }^{5}$ Sri - Turatmiyah, "Kedudukan Hukum Perjanjian Perkawinan Pasca Putusan Mahkamah Konstitusi No.69/PUU-XIII/2015,” Syiar Hukum : Jurnal Ilmu Hukum, Vol. 16, No. 1, September, 2019, P. 2.

${ }^{6}$ Sonny Dewi Judiasih, Deviana Yuanitasari, dan Revi Inayatillah, Op. Cit., 85, P. 6.

${ }^{7}$ Arief Cholil, "Implementation Agreement By Mixed Marriage Based On Act No. 1 of 1974 Concerning Marriage After Constitutional Court Ruling No. 69 / PUU-XIII / 2015 (Study of Notary Role)," Vol. 5, No. 4, 2018, P. 12.

${ }^{8}$ Damian Agata Yuvens, Op. Cit., 29, P. 8.

${ }^{9}$ Ibid., P. 14.
} 
contents of the marriage agreement are not violating the boundaries of legal, religion, morality and public order. The provisions of Article 29 paragraph (1) of the Marriage Law do not explicitly stated when the ratification should be carried out but it does specify that since it is ratified, the contents of the marriage agreement also apply to third parties. ${ }^{1}$

c. Formulation of the Publicity Principle of Post Nuptial Agreement Regulations to Provide Legal Protection for Creditors

The concept of legal certainty of the publicity principle of marriage agreement needs to be applied to avoid legal confusion. ${ }^{2}$ In phrase "Principle of Legal Certainty" is the principle of a state of law that prioritizes the foundation of statutory regulations, propriety and justice in every state administrators policy. ${ }^{3}$ Regarding the concept of legal certainty, Jimmy Zeravianus Usfunan in his research revealed that legal certainty in the view of positivism can identify the requirements, including:

a) The Regulations are legalized by sovereign institutions.

b) The rules established should source from a higher regulation.

c) A clarity of provisions in the rules.

d) A certainty in the application of the law in accordance with what is promulgated (in order to limit power, and people understand their rights and obligations).

e) A Legal certainty gives an opportunity for these regulations to be changed according to developments (considering court decisions and other social facts).

On the other hand, Mathia Klatt brought up a juridical problem i.e., legal indeterminacy cannot be determined. This legal indeterminacy may be caused by various factors, such as vagueness. Thus, an obscure norm is known as vagueness of norm and ambiguity. Ambiguity is a confusion of meaning in language. Its equivalent to ambivalence or the state of expanding between two actions. Ambiguity and ambivalence greatly affect the level of "trust" in the power elite. Trustworthiness is the society's expectation of a consistent and correct need based on shared norms. On the other hand, ambiguity of speech and ambivalence of action are two aspects that have the potential to accumulate distrust of the government regime.

The urgency of legal certainty concept is used in this research because normatively, laws and regulations must be clearly defined, meaning that it should not cause multiple interpretations and do not create a vague and void of norms. A marriage agreement that does not violate the law is an agreement that meets the legal requirements according to BW and the provisions in the Marriage Law which require an agreement by the parties. ${ }^{4}$ The agreement is an important event which is preceded by another important event as its main point, namely marriage, as an implication of population administration order to fulfill the principle of publicity of the marriage agreement and to bind a third party, as evidence in the trial. Marriage agreement after the Constitutional Court Decision Number 69/PUU-XIII/2015 concerning the judicial review of the Act Number 5 of 1960 on Basic Agrarian Principles and Act Number 1 of 1974 on Marriage against the 1945 Constitution of the Republic of Indonesia, which states that the Marriage Agreement can be made after the marriage has taken place (Post Nuptial Agreement) raises various dilemmas regarding the concept of 'time' the marriage agreement issued and legal protection for related third parties. The principle of publicity enforced in marriage agreements by a marriage registrar is indicated to have weaknesses, which creates legal uncertainty. The weaknesses are such as legal smuggling by the husband and wife and their dishonesty in showing the marriage agreement to a third party. The publicity principle is a communication process and access to third parties, i.e., the creditor regarding a legal action of assets. Thus, to maximize the applicability of the principle of publicity, the researcher examines the need for reformulation of information technology-based marriage arrangements registration that must be provided by marriage institutions in Indonesia.

Previously, Indonesian marriage institutions have introduced marriage cards to proof marital status. The marriage card is a new innovation in building technology of a marriage management information system or sistem informasi manajamen nikah (hereinafter referred to as SIMKAH) which aims to facilitate administration and banking or other civil registration purposes that require husband and wife's legal marital status. SIMKAH is a webbased online application which is a marriage data directory integrated with the Ministry of Home Affairs' Population Administration Information System or Sistem Informasi Administrasi Kependudukan (hereinafter referred to as SIAK) Application and the Ministry of Finance's Online PNBP Information System (SIMPONI). The marriage card is flexible to carry, it also has data accuracy by attaching a spouse photo, a barcode that shows the facial data, names and date of marriage of the husband and wife.

The accuracy and easiness of marriage cards can be adopted in the process of recording marriage agreements.

\footnotetext{
${ }^{1}$ Wisda Rauyani Efa Rahmatika dan Akhmad Khisni, “Analisis Yuridis Atas Perjanjian Perkawinan Ditinjau Dari Undang-Undang No.1 Tahun 1974 Tentang Perkawinan Dan Implikasi Putusan MK No.69/PUU-XIII/2015,” Vol. 4, No. 3, 2017, P. 5.

${ }^{2}$ Sulikah Kualaria dan Dr Abdul Rachmad Budiono, Op. Cit., 82.

${ }^{3}$ Ibid., P. 5.

${ }^{4}$ Mambaul Ngadimah, "Formulasi Perjanjian Perkawinan Pasca Putusan MK No. 69/PUU-XIII/2015," Kodifikasia, Vol. 11, No. 1, Agustus, 2017, P. 94
} 
The web-based application of SIMKAH and the marriage card as authentic evidence of marriage registration needs to provide or add an application that the interest parties can access. This access can be in the form of barcodes and secret codes on online-based marriage agreements provided in a marriage card or by other mechanisms. According to the researcher's analysis, the online-based marriage agreement can maximize the applicability of the principle of publicity by maintaining the confidentiality of the couples agreement, besides, it is to avoid falsification of marriage agreements because the original contract has been listed on the web application. Legal certainty of the marriage agreement is everything published on the web, so that if the husband and wife cannot show the agreement they made, the creditor or third party can conclude that the spouse have never made a marriage agreement or if in the future the couples renew the contract, then the marriage agreement applicable to the third party/related creditor is at the time the agreement made.

\section{Conclusion}

Based on the above elaboration, this research has concluded these following points, namely:

(d) The essence of a marriage agreement is a legal act that belongs to the realm of contract law, namely a written agreement made before or during the marriage bond. Marriage agreements have different characteristics from agreements in general, where the validity requirements must refer to Article $1320 \mathrm{BW}$, namely agreement, competence, certain objects and allowed causes. The measuring rod refers to the Act Number 16 of 2019 which is an amendment of the Special Marriage Law concerning Age of Marriage. Essentially, this agreement is a predominantly agreement regarding the assets of the prospective bride and groom to avoid their assets loss before the marriage takes place, and it is still necessary to be legalized by a marriage registrar or a notary Therefore, in entering into an agreement, a couple can deviate the principles or patterns stipulated in the statutory regulations, and ignore the Article 35 of the Marriage Law under conditions that it has been agreed by both parties and it does not violate the law, public order and morals.

(e) The strength to bind the principle of publicity in a marriage agreement (post nuptial agreement), the perspective of legal protection for creditors is as a guarantee and perfect authentication power that guarantees legal certainty for the parties concerned. Marriage agreement must be stated in the form of an authentic deed thus it has strong authentication power to provide a legal certainty on the rights and obligations of husband and wife towards the property agreed, considering that the agreement has high consequences, and it concerns the interests of third parties or creditors. The principle of publicity in a marriage agreement provides an opportunity for creditors to see and understand the existence of the contract so that they can examine and submit to the marriage agreement made by the husband and wife.

(f) The formulation of the principle of publicity of a marriage agreement regulation (Post Nupital Agreement) to provide legal protection for creditors is by integrating the marriage card and the marriage agreement as legal identity. Web-based Marriage Management Information System (SIMKAH) applications and marriage cards as authentic evidence of marriage registration must also provide applications that can view upgraded marriage agreements online, barcode and certain secret codes as a manifestation of the principle of online-based publicity while maintaining the confidentiality of the agreement made by the parties. The recording of marriage agreement at the Civil Registration Office is directly recorded on the application as a form of legal certainty concerning the assets of the husband and wife, thus in addition to facilitate administrative management, online registration is also able to provide legal protection for third parties or creditors. The marriage card integrated with an online-based marriage agreement is used as authentic evidence issued by the government in carrying out the recording of the marriage agreement, therefore if the couples cannot show the marriage agreement to the creditor, the creditor can conclude that the marriage agreement is invalid and never existed.

\section{Recommendations}

Some recommendations are provided related to the above discussion, namely:

1. To the parties involved in the marriage contract or the prospective husband and wife who will make a marriage agreement, it is emphasized that marriage is a physical and spiritual bond. To achieve this inner and outer ties, it requires the principle of openness to property and everything that will be agreed upon thus the marriage agreement is made to reflect the equal position between the prospective husband and wife and/or without the existence of dominant power on either party. The openness will facilitate the notary to direct and make a marriage agreement in accordance with statutory regulations.

2. It is expected that the notaries will not be passive by relying on the formal truth of the parties who are about to enter into a marriage agreement. They are expected to be more careful, detailed, and active in seeking material truth for making marriage agreements. It is to avoid abuse occurred towards the situation by the two prospective husband and wife or one of them, and to avoid fault I the agreement made.

3. It is necessary that the legislator to reform the Act Number 1 of 1974 concerning Marriage. It is important to regulate new norms of the law regarding marriage agreements after the Constitutional Court decision 
Number 69 of 2015. Since there are no further regulations on the conception of a marriage agreement at the time the marriage takes place. Having clear regulations of its related matter is important to avoid the existence of legal smuggling by husband and wife.

4. Legislators are required to make implementing rules for notaries for making marriage agreements before, during and at the time of marriage. This arrangement may be a legal certainty for the notary if violation towards the law of the agreement done by the parties. Thus, the notary is safe from any criminal abuse of their authoritative position as a deed maker.

\section{References}

Abd. Nashr Taufik Al-Athar, Saat Anda Meminang, Terj. Abu Syarifah dan Afifah, Jakarta: Pustaka Azam, 2000 Abdul Hariss dan Nurul Wulan Kasmara, "Tinjauan Yuridis Akibat Hukum Perjanjian Harta Bersama yang Dibuat Oleh Suami Istri Setelah Perkawinan Berdasarkan Putusan Mahkamah Konstitusi Nomor 69/PUU-XIII/2015,' Wajah Hukum, Vol. 3, No. 1, 2019.

Ahmad Azhar Basyir, Hukum Perkawinan Islam, Yogyakarta: Fakultas Hukum Universitas Islam Indonesia, 1995 Annisa Istrianty dan Erwan Priambada, "Akibat Hukum Perjanjian Perkawinan Yang dibuat Setelah Perkawinan Berlangsung," Sebelas Maret University Privat Law, Vol. 3, No. 2, 2016.

Arief Cholil, "Implementation Agreement By Mixed Marriage Based On Act No. 1 of 1974 Concerning Marriage After Constitutional Court Ruling No. 69 / PUU-XIII / 2015 (Study of Notary Role),” Vol. 5, No. 4, 2018

Damian Agata Yuvens, "Analisis Kritis terhadap Perjanjian Perkawinan dalam Putusan Mahkamah Konstitusi Nomor 69/PUU-XIII/2015," Jurnal Konstitusi, Vol. 14, No. 4, 2018

Dian Ety Mayasari, "Tinjauan Yuridis tentang Perjanjian Perkawinan Setelah Adanya Putusan Mahkamah Konstitusi Nomor 69/PUU-XIII/2015,”, ., Vol. 51, No. 1, 2017

Endang Sumiarni, Kedudukan Suami Isteri Dalam Hukum Perkawinan, Kajian Kesetaraan Jender Melalui Perjanjian Kawin, Yogyakarta: Wonderful Publishing Company, 2004

Erdhyan Paramita, Akibat Hukum Perjanjian Perkawinan Yang Tidak Disahkan Oleh Pegawai Pencatat Perkawinan, Jurnal Repertorium Volume IV No. 2 Juli - Desember 2017

Habib Adjie, 2008, Hukum Notaris Indonesia: Tafsir Tematik Terhadap UU No. 30 Tahun 2004 Tentang Jabatan Notaris, Refika Aditama

Habib Adjie, 2009, Sekilas dunia Notaris \& PPAT Indonesia: kumpulan tulisan, Mandar Maju

Herlien Budiono, Ajaran Umum Hukum Perjanjian dan Penerapannya di Bidang Kenotariatan, Citra Aditya Bakti, 2011.

M. Alvi Syahrin, “Actio Pauliana: Konsep Hukum dan Problematikanya,” Lex Librum: Jurnal Ilmu Hukum, Vol. 4, No. 1, 2017.

Mambaul Ngadimah, "Formulasi Perjanjian Perkawinan Pasca Putusan MK No. 69/PUU-XIII/2015," Kodifikasia, Vol. 11, No. 1, Agustus, 2017

Moch. Isnaeni. Hukum Perkawinan Indonesia. Bandung: Refika Aditama, 2016

Oken Shahnaz Pramasantya, "Perjanjian Perkawinan Pasca Putusan Mahkamah Konstitusi Nomor 69/PUUXIII/2015," Jurnal Cakrawala Hukum, Vol. 8, No. 2, Desember, 2017

Oly Viana Agustinee, Politik Hukum Perjanjian Perkawinan Pasca Putusan Mahkamah Konstitusi Nomor 69/PUU-XIII/2015 Dalam Menciptakan Keharomonisan Perkawinan, Jurnal Rechtsvinding-Volume 6, Nomor 1-April 2017

Raden Subekti, Aneka perjanjian, Penerbit Press Citra Aditya Bakti,1995.

Rahmida Erliyani, Aspek Hukum Perjanjian Perkawinan, Penerbit K-Media, 2016.

Reza Fahlevi Bachtiar, "Due To Legal Marriage Without Married Agreement Relating To The Existence Of Bankruptcy," Vol. 5, No. 2, 2018

Sonny Dewi Judiasih, Deviana Yuanitasari, dan Revi Inayatillah, "Model Perjanjian perkawinan yang Dibuat setelah Perkawinan Berlangsung Pasca Berlakunya Putusan Mahkamah Konstitusi Nomor 69/PUUXIII/2015," Masalah-Masalah Hukum, Vol. 47, No. 3, 2018.

Sonny Dewi Judiasih. Harta Benda Perkawinan., Kajian terhadap kesetaraan hak dan kedudukan Suami dan Istreri atas kepemilikan harta dalam perkawinan. Bandung: Refika Aditama, 2015

Sri - Turatmiyah, "Kedudukan Hukum Perjanjian Perkawinan Pasca Putusan Mahkamah Konstitusi No.69/PUUXIII/2015," Syiar Hukum : Jurnal Ilmu Hukum, Vol. 16, No. 1, September, 2019

Sri Subekti, Liliana Tedjosaputro, dan Mr Mashari, "Legal Protection Concept: Separate Maintenance for the Third Party in Prenuptial Agreement," International Journal of Civil Engineering and Technology, Vol. 11, No. 1, 2020

Sri Subekti, Liliana Tedjosaputro, dan Mr Mashari, "Legal Protection Concept: Separate Maintenance for the Third Party in Prenuptial Agreement," International Journal of Civil Engineering and Technology, Vol. 11, No. 1, 2020.

Subekti, Pokok-Pokok Hukum Perdata, Jakarta: Intermasa, 1993- 25 ${ }^{\text {th }}$ Edition 
Sudarsono. Hukum Perkawinan Nasional. Jakarta: Rineka Cipta, 1991

Sukardi, Kajian Yuridis Perjanjian Perkawinan Menurut Kitab Undang-Undang Hukum Perdata, Undang-Undang Nomor 1 Tahun 1974 dan Kompilasi Hukum Islam. Jurnal Khatulistiwa-Journal of Islamic Studies, Volume 6 No.1 March 2016

Syaifullahi Maslul, "Putusan Mahkamah Konstitusi Nomor 69/PUU-XIII/2015 Ditinjau dari Pemenuhan Hak-Hak Asasi Manusi dan Asas-Asas Pembentukan Perjanjian," Jurnal Mahkamah: Kajian Ilmu Hukum Dan Hukum Islam, Vol. 1, No. 2, 2016.

Sylvia Widjaja, “Aneka Permasalahan Mengenai Perjanjian perkawinan, Pengesahan atau Pencatatan,” Dialogia Iuridica: Jurnal Hukum Bisnis dan Investasi, Vol. 7, No. 1, May, 2017.

Tan Kamello dan Syarifah Lisa Andriati. Hukum Orang dan Keluarga. Medan: USU Press, 2011

Tengku Erwinsyahbana, "Sistem hukum perkawinan pada Negara hukum berdasarkan pancasila," jurnal ilmu hukum, Vol. 3, No. 1, 2012

Titik Triwulan tutik. Hukum Perdata Dalam Sistem Hukum Nasional. Jakarta: Kencana, 2008

Wahyono Darmabrata dan Surini Ahlan Sjarif. Hukum perkawinan dan Keluarga di Indonesia. Jakarta: Rizkita, 2015

Wahyono Darmabrata, "Hukum Perdata Asas-Asas Hukum Waris," Fakultas Hukum Universitas Indonesia, Jakarta, 2003.

Wahyono Darmabrata, "Hukum Perdata Perkawinan,” Jakarta: Rizkita, 2009.

Wahyono Darmabrata, Hukum Perdata Asas-Asas Hukum Orang dan Keluarga, Jakarta: Gitamajaya, 2004.

Wisda Rauyani Efa Rahmatika dan Akhmad Khisni, "Analisis Yuridis Atas Perjanjian Perkawinan Ditinjau Dari Undang-Undang No.1 Tahun 1974 Tentang Perkawinan Dan Implikasi Putusan MK No.69/PUU-XIII/2015," Vol. 4, No. 3, 2017

Zulfiani, Perlindungan Hukum Terhadap Penguasaan Harta Bawaan Dan Harta Bersama Setelah Perceraian Menurut Uu No. 1 Tahun 1974 Tentang Perkawinan Berbasis Keadilan, Jurnal Pembaharuan Hukum Volume II No. 2 May - August 2015 